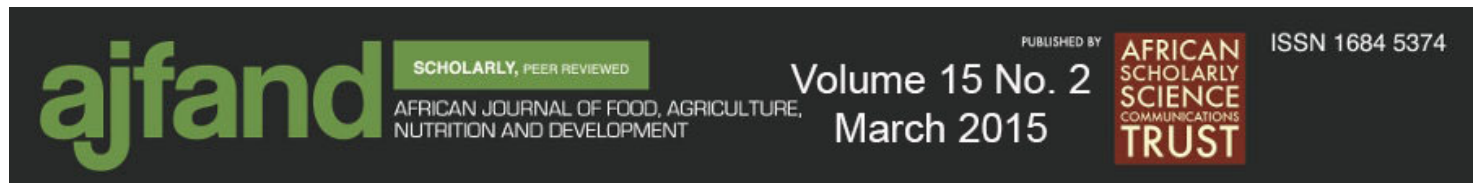

\title{
EVALUATION OF FOUR APICULTURAL PRODUCTS FOR HIVE COLONIZATION BY HONEY BEES (Apis mellifera adansonii) (HYMENOPTERA: APIDAE) AND PRE-COLONIZATION PESTS
}

Babarinde SA ${ }^{1 *}$, Olaleke SA ${ }^{1}$, Akinyemi $\mathrm{AO}^{2}$, Adebayo $\mathrm{TA}^{1}$ and JI Olaifa ${ }^{1}$

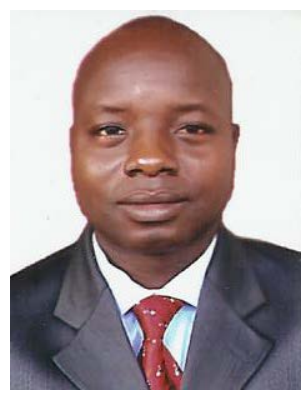

Samuel Adelani Babarinde

*Corresponding author email: sababarinde@lautech.edu.ng / samdelani@yahoo.com

1. Department of Crop and Environmental Protection, Ladoke Akintola University of Technology, P. M. B. 4000, Ogbomoso, Nigeria.

2. Department of Agronomy, Osun State University, College of Agriculture, Ejigbo Campus, P.M.B. 4494, Osogbo, Nigeria 


\begin{abstract}
Four apicultural products (honey, bee wax, slum gum and propolis) were evaluated for their potentials to attract the African honey bee (Apis mellifera adansonii) colony into artificial hives and their effect on infestation by apicultural insect pests. Ten grammes each of propolis, bee wax and slum gum and $10 \mathrm{ml}$ of honey were applied at the flight entrance, walls of the hives and on the top bars. Data were collected on type and number of pre-colonization pests, hive colonization, colony weight gain, weight of matured harvested combs and weight of extracted honey from the harvested combs. Statistical analysis of the data was carried out using analysis of variance and means were separated with Tukeys' HSD at 5\% level of probability. Slum gum-baited hives were the first to be colonized (10 days post hive installation) (DPI), followed by bee wax (26.5 DPI). Bee wax however had the highest percentage hive colonization $(66.67 \%)$ which was not significantly $(\mathrm{P}>0.05)$ different from $33.33 \%$ observed in other apicultural products. Weight gain on weekly basis did not follow a regular pattern for 2-10 weeks after colonization (WAC); but at 12-16 WAC, hives baited with bee wax had the highest weekly weight gain. In terms of total harvest, the performance of the different baiting materials was as follows: slum gum $>$ bee wax $>$ honey $>$ propolis. However, percentage honey yield was highest in hives baited with bee wax and lowest in propolis-baited hives. The two pests encountered at the pre-colonization stage were waiver ant (Oecophylla longinuda) and sugar ant (Camponotus consobrinus). O. longinuda was significantly $(\mathrm{P}<0.05)$ highest $(17.33)$ in honey baited hives than any other baiting material at 2 DPI. Slum gum and honey attracted more sugar ants at 2-4 DPI than bee wax. At 3 DPI, $O$. longinuda was significantly $(\mathrm{P}<0.05)$ higher in slum gum than bee wax; but the later performed better with significantly lower level of pre-colonization pest infestation.
\end{abstract}

Key words: pest, wax, honey, propolis, slum-gum 


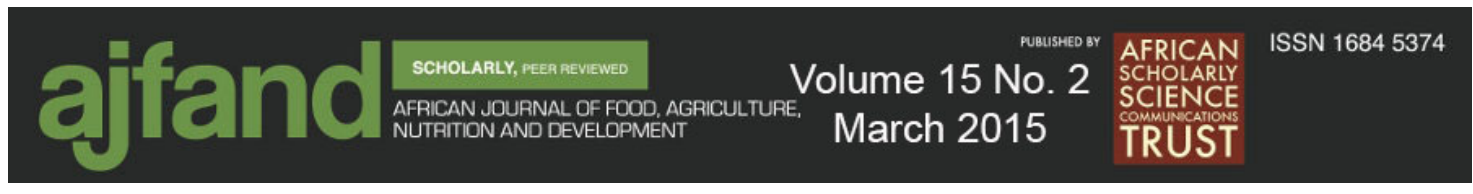

\section{INTRODUCTION}

The African honeybee (Apis mellifera adansonii) is kept mainly for pollination of crops and its diverse products which include honey, pollen, propolis, bee venom, royal jelly and slum gum. The potential use of honey bee slum gum as an ingredient for broiler chicken feed has previously been reported [1]. The ability to increase the supply of the bee hive products depends on several factors including hive that houses honey bee and its products and products used to attract bee colony into the hives [2]. A major problem of beekeepers in developing countries is late colonization of hive. Several beginners were frustrated when their baited hives could not be colonized by bees despite the usage of baiting materials that were recommended by experienced beekeepers within their localities. There have been several studies on different apicultural products as colony attractant in the tropics, for instance, the use of old raw combs to attract bee colony in Himachal, Himalaya [3]. The effectiveness of propolis, wax and cassava powder was compared in the North-western agro-ecological zone of Uganda and it was discovered that propolis performed better than the other tested attractants in term of percentage hive colonization [4]. The use of honey as colony attractant in Nigeria was reported by Aina and Owonibi [5]. Other researchers [1, 2, 6, 7] reported the use of bee wax for baiting of hives, as a popular baiting material in Nigeria. It is worth noting that research that attempted to compare different apicultural products as baiting materials are relatively scarce. Apicultural pests have been identified as one of the major biotic factors affecting successful beekeeping in different parts of the world $[6,8,9,10,11,12]$. These pests could be categorised as pre-colonization or post-colonization pest, depending on the status of installed hives when the pest incidence occurred. It is opined that the baiting materials can influence the type and intensity of apicultural pests in an area, but this has not been established through an empirical study. Although, there have been some documented studies on performance of baits of different origin as attractants of bee colony into hives, there is paucity of information on comparison of other apicultural products with bee wax as colony attractants, at least in tropical Africa [4, 13]. To a very large extent, rural beekeepers in the tropics have traditionally used bee wax as colony attractant more than they used other apicultural products [13, 14, 15, 16, 17]. The objective of this study was to evaluate the effectiveness of four different apicultural products obtained from the same source on hive colonisation, honey yield and precolonization insect pest infestation.

\section{MATERIALS AND METHODS}

\section{Experimental site}

The research was carried out at Ladoke Akintola University of Technology (LAUTECH), Ventures Apiary, Ogbomoso, Nigeria. The region's climate is non-humid tropical and falls within Southern Guinea Savanna of Nigeria $\left(8.08^{\circ} \mathrm{N} ; 4.14^{\circ} \mathrm{E}\right.$ at an altitude of $300 \mathrm{~m}$ above sea level) with a rainfall of $1400 \mathrm{~mm}$, characterized by bi-modal rainfall with peaks in July and September and marked with dry and wet seasons. The apiary was on an acre of land with conservation of flora sources. The species of the flora present at the experimental site included Parkia biglobosa, Mangifera indica, Glyricidia serpeum, Aspillia africana, Azadirachta indica, Anacardium occidentalis and Pennisetum purpureum. Arable crops within the location included cassava, yam, maize, pea nut and 
cowpea. Their management practices were traditional without the use of inorganic fertilizer or synthetic pesticides. The tree crops and the evergreen plants in the location, besides supplying apicultural resources to the bees equally provided sufficient shade that prevented the hive from solar radiation but enabled sunshine for apicultural activities. The ecological characteristics in the experimental site favoured active foraging activities of honeybees [18]. Water source was available within a 200-m radius to the site. The site was reasonably flat, well drained and protected from hazardous natural wind which could blow off the hives.

\section{Hive Description}

Hives made of Gmelina arborea L. wood were constructed according to standard model [19]. The four sides of the hives were covered with wood given the flight entrance at the front elevation with a wooden landing board at the base and wooden top bars arranged parallel to each other on top of the hive.

\section{Baiting and installation of hive}

The hives were baited and installed on the $29^{\text {th }}$ December, 2011. Prior to hive baiting, initial weight of each hive was determined with the aid of top loading weighing balance (Camry ${ }^{\circledR}$ Empersas, China). Four apicultural products (propolis, wax, slum gum and honey) obtained from the same apiary were used for the experiment. Ten grammes each of propolis, bee wax and slum gum and $10 \mathrm{ml}$ of honey were applied at the flight entrance, walls of the hives and on the top bars. Honey was applied with the aid of a syringe (Menojet ${ }^{\circledR}$, China). Twelve baited hives were installed on rectangular iron stand and corrugated asbestos used as roofs [6, 7]. The experiment was replicated three times and arranged in a completely randomized design.

\section{Incidence of pre-colonization pests, development of bee colony and harvesting of matured honey}

The type and number of pre-colonization pests encountered in installed hives were recorded daily from one day post hive installation till hive colonization. Thereafter, the number of colonized hives was recorded per treatment. Weight gain of each colonized hive was taken on weekly basis with the same sensitive top-loading weighing balance used at hive installation, by subtracting the final weight from initial weight. Average weight gain was determined as total weight gain divided by number of hives that cumulated to the total weight. The accumulation of matured honey in the bee hives was monitored through visual inspection. Harvesting and processing was done according to the standard [12].

Data were collected on the following:

(a) Weight of matured combs harvested from each colonized hive

(b) Weight of extracted honey from the harvested combs. Thereafter, percentage honey yield was determined as:

Percentage honey yield $=\underline{\text { Weight of extracted honey from matured combs } x 100 .}$ Weight of matured combs harvested from the hive 


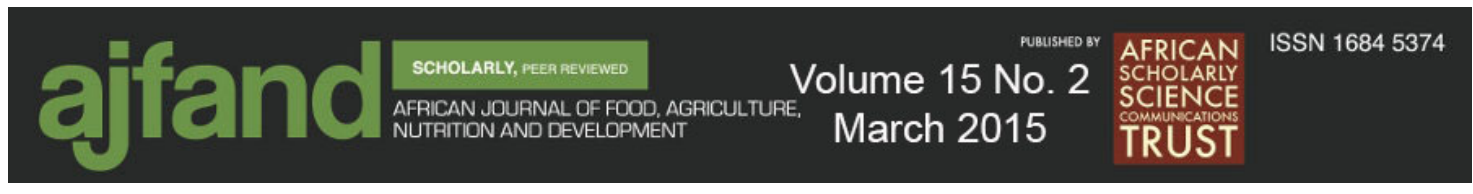

\section{Statistical Analysis}

The data were analyzed using the analysis of variance (ANOVA) and where there was a significant treatment difference, means were separated using Tukeys' HSD at 5\% probability level, with the aid of SPSS Software [21].

\section{RESULTS}

\section{Effect of different baiting materials on hive colonization and bee colony weight gain and yield}

The effect of different baiting materials on colony weight gain was not significant $(\mathrm{P}>0.05)$. Weight gain in all the treated hives increased with time and reached the peak at 16 weeks after baiting, with bee wax-baited hives having the highest weight gain (kg). This was followed by slum gum while propolis had the least weight gain (Figure 1). The first baiting material to cause hive colonization was slum gum (10 days post hive installation) (10 DPI). This was followed by bee wax (26.5 DPI) while propolis-bated hive took longest to colonization. However, bee wax had the highest percentage hive colonization $(66.67 \%)$ which was not significantly $(\mathrm{P}>0.05)$ different from $33.33 \%$ observed in slum gum, honey and propolis (Figure 2). Slum gum however had the highest total and honey yield (1.1kg and $0.7 \mathrm{~kg}$ respectively). This was followed by bee wax and honey-baited hives while the least yield was observed in propolis-baited hives $(0.1 \mathrm{~kg}$ and $0.05 \mathrm{~kg}$ respectively) (Figure 3). Percentage honey yield was highest in hives baited with slum gum and lowest in propolis-baited hives (Figure 4).

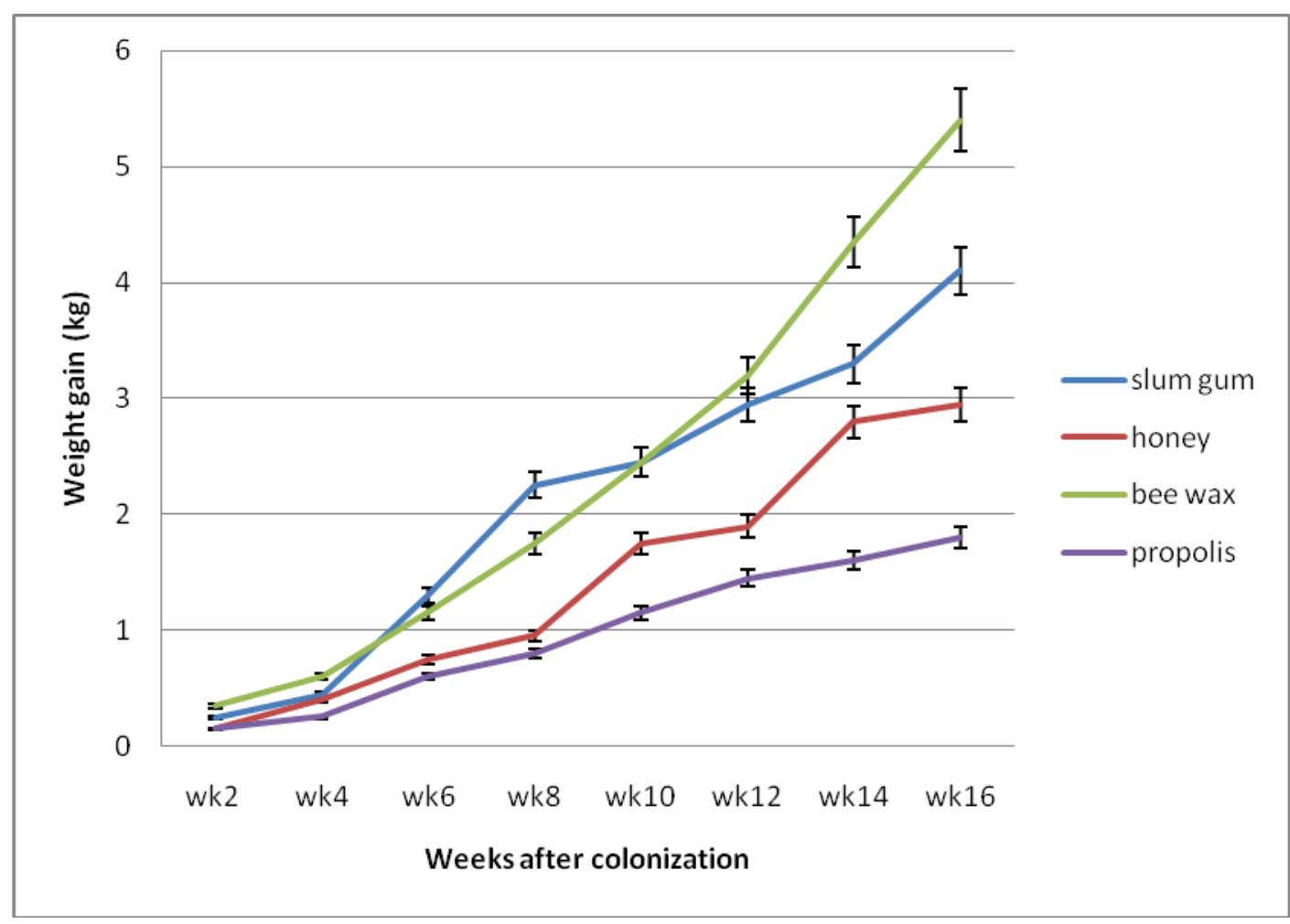

Figure 1: Weight gain of colonized hives baited with four different baiting materials 

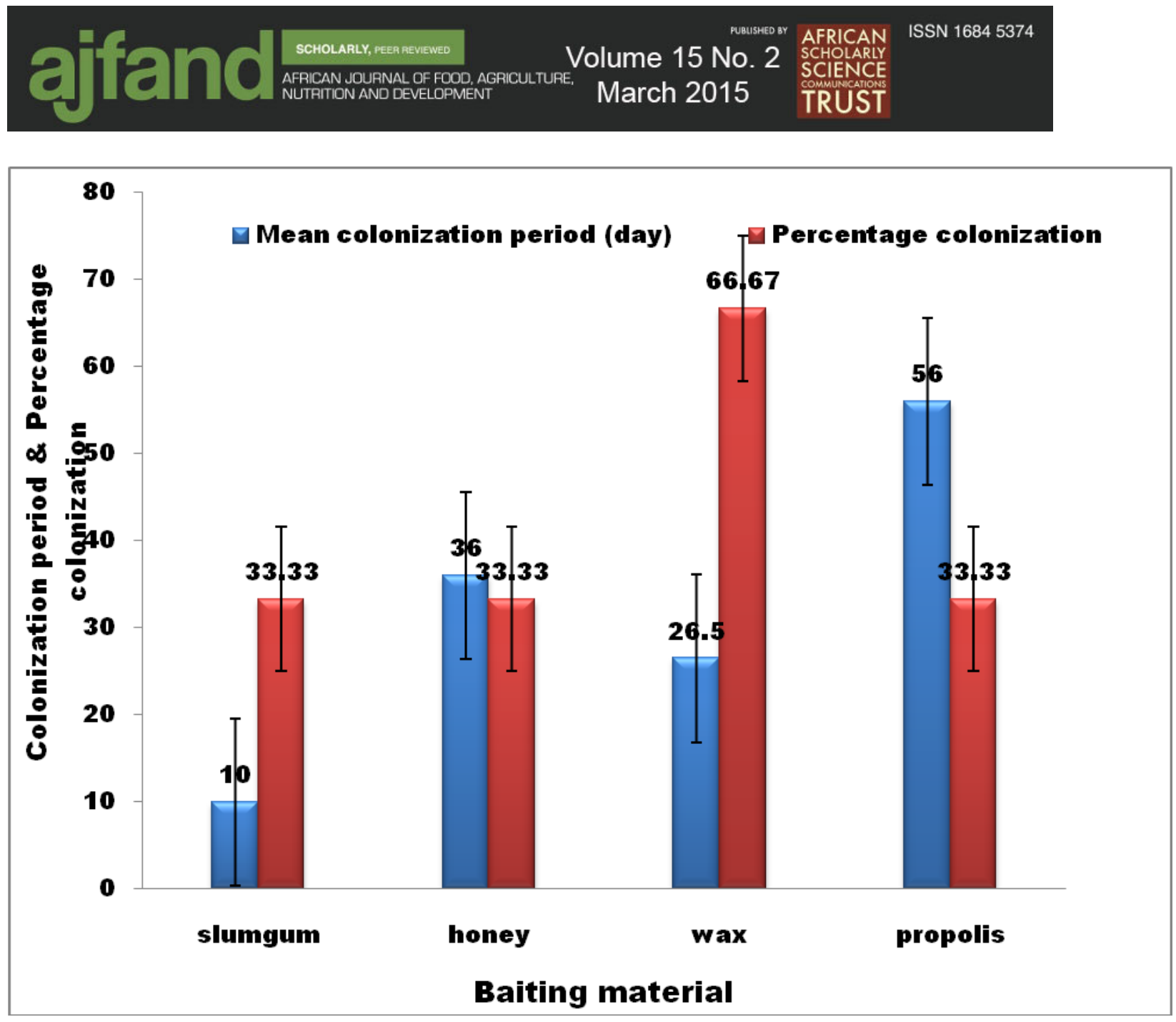

Figure 2: Effect of baiting materials on hive colonization 

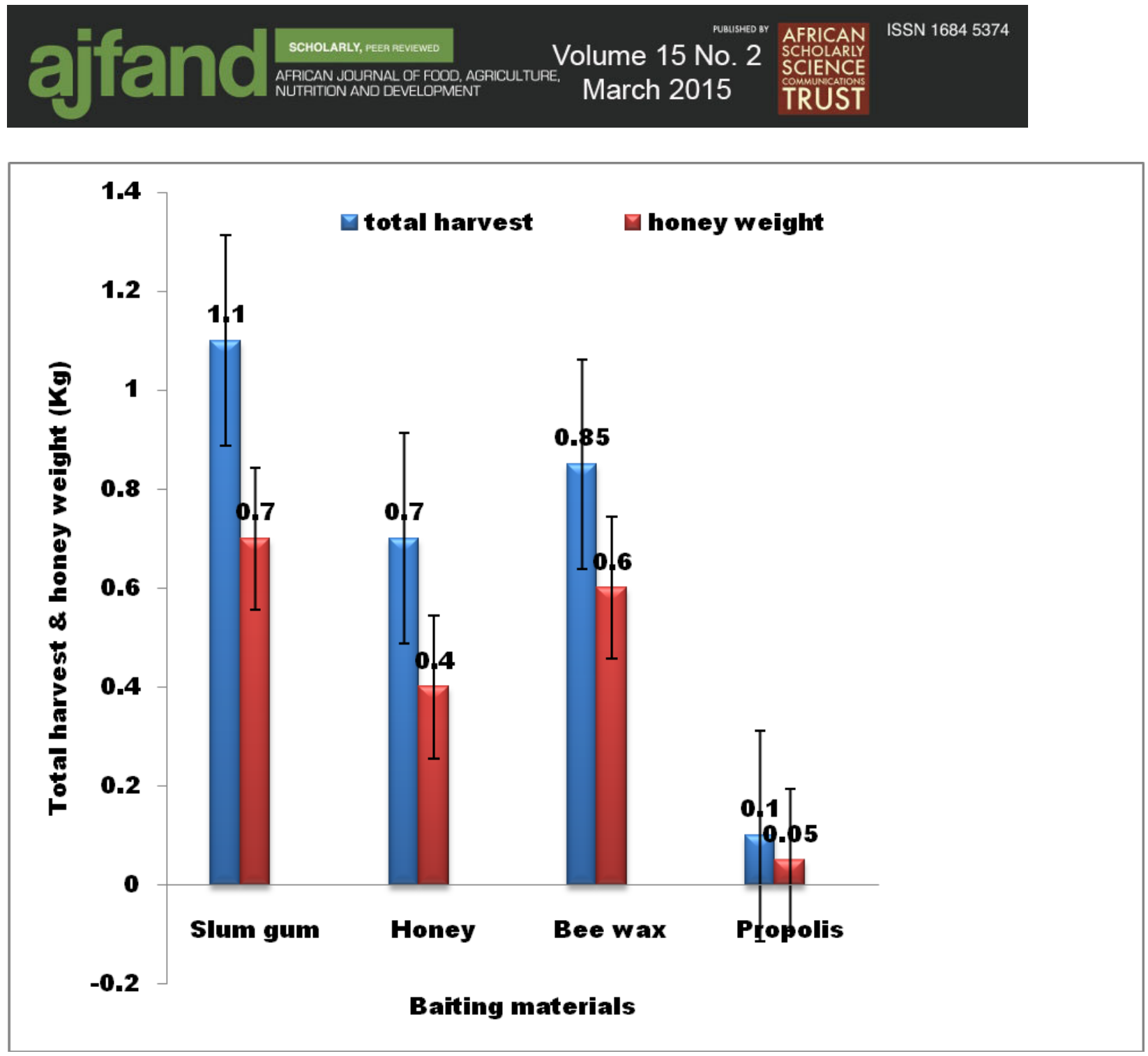

Figure 3: Yield of honey bee colony in hives baited with four different baiting materials 

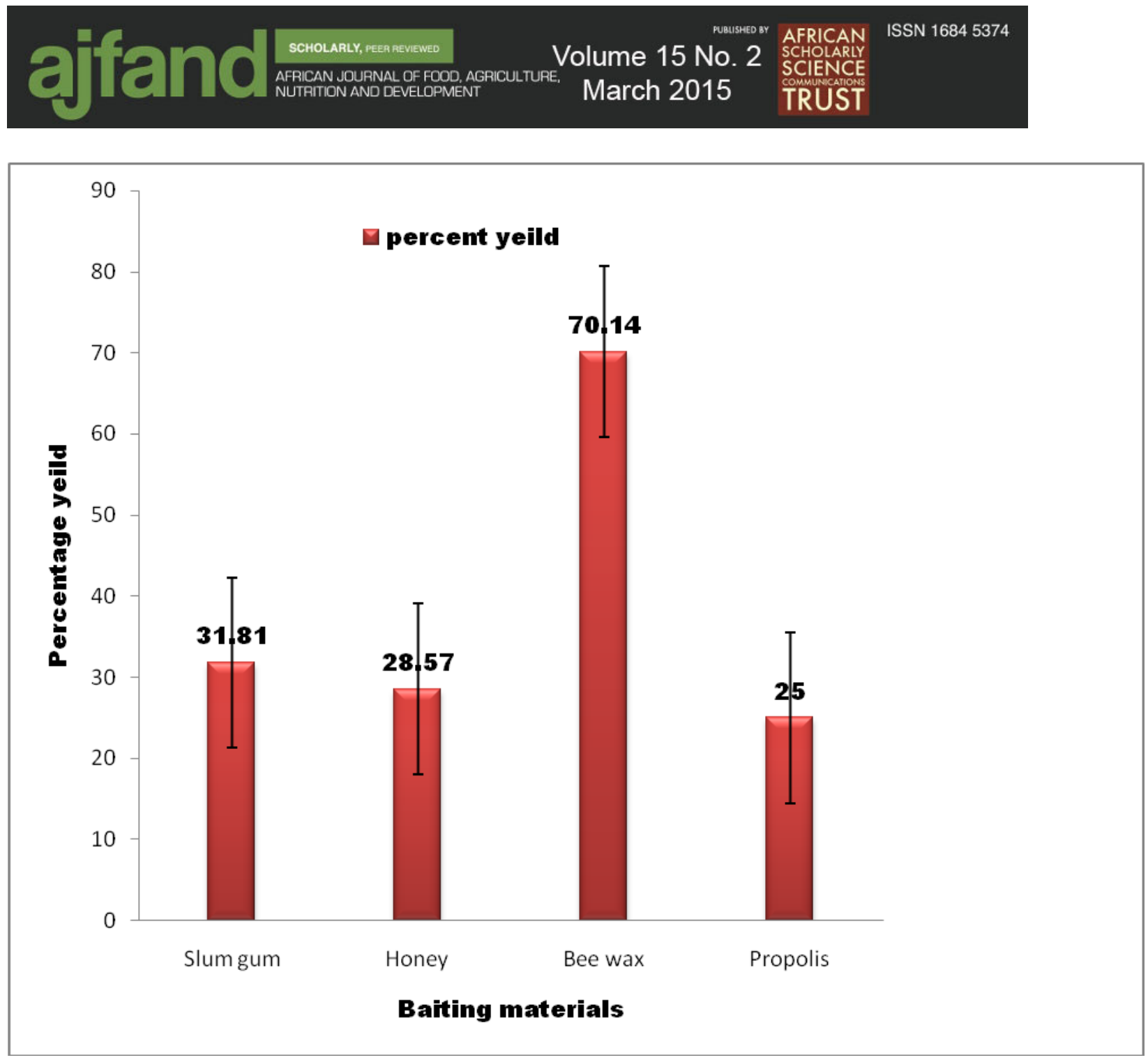

Figure 4: Percentage honey yield from matured honey comb in hives baited with four different baiting materials

\section{Effect of different baiting materials on pest profile of baited hives}

The two pests encountered at pre-colonization stage were waiver ant (Oecophylla longinuda) and sugar ant (Camponotus consobrinus). O. longinuda was significantly $(\mathrm{P}<0.05)$ highest in honey treated hives $(17.33)$ compared to other baiting materials at 2 days post hive installation (DPI) while at $3 \mathrm{DPI}$, O. longinuda had the highest population in slum gum treated hives. Slum gum and honey attracted sugar ants at 2-4 DPI while bee wax and propolis did not attract sugar ant but attracted $O$. longinuda at 4 DPI (Table 1).

\section{DISCUSSION}

A major problem affecting many beginner apiculturists is failure of hives to colonize. The four tested materials showed potentials to attract honey bee colony. However, higher percentage colonization was observed in wax than other apicultural products. This was consistent with the findings of previous researchers $[2,6,7]$. The reason was that the odour of wax persisted over a longer time period than other products like honey and 
propolis. Slum gum usually has some wax particles that can be collected with it during the rending of combs to wax. That could be the reason for its better performance than pure honey and propolis in terms of mean colonization period. In a study conducted in Nigeria, colonization rate of $50 \%$ was observed when Kenya top bar hives were baited with bee wax [2]. However, the superior ability of propolis over bee wax as colony attractant had been reported in Uganda. Incidentally, the authors did not state possible reasons for that observation [4].

The result of the pest profile indicated two major pre-colonization pests viz: O. longinoda and C. consobrinus. C. pennsylvanicus had been reported as an apicultural pest in Kwara State, Nigeria [11]. O. longinoda had been listed as a major threat to the apiculture in southwestern Nigeria [6]. Low level of incidence of these pests in hives baited with bee wax further justified the potency of bee wax in honey bee colonization. Although the reason for low pest population in bee wax and propolis was not investigated in this study, it has been reported that worker honey bees encapsulate groups of small hive beetle (Aethina tumida) with propolis as defence mechanism [21]. Pest control has been categorized as an important routine management known to enhance colony performance such as reduced absconding, improved colony strength and higher hive yields [22]. It has also been noted to minimize absconding rate [23]. Since bee wax recorded higher percentage hive colonization than other baiting materials and lower pest incidence, its outstanding candidacy as a baiting material above other studied apicultural products was established. Early colonization and high honey yield observed in slum gum made it also recommendable to farmers as a baiting material. Presently, slum gum has not been popularly used as a baiting material and has always been thrown away after rendering of wax from the combs. This study has established an aspect of its untapped benefits for the apicultural industry. Since the result of this study showed that slum gum harboured $O$. longinoda as a pre-colonization pest, provision should be made for the control of the pest when this product is used as honeybee colony attractant. Use of slum gum as a baiting material will reduce the cost incurred from purchase of bee wax and / or increase income realizable from the sale of bee wax: an exportable product, which has many industrial uses.

\section{CONCLUSION}

All the apicultural products used in this study attracted bee colony, but bee wax performed better, being with significantly lesser incidence of pre-colonization pests. The study established an untapped benefit of slum gum to the apicultural industry as an attractant for bee colonies into baited hives. Since slum gum is always discarded as a waste product after rendering of wax, its potential to reduce cost of production and to increase income from sale of bee wax (which is being traditionally used as baits) was established. It is, therefore, recommended for use as a baiting material in the tropical areas that share similar characteristics with the studied agro-ecological zone. However, when slum gum is to be used as colony attractant, technical means of preventing precolonization pests should be put in place. 


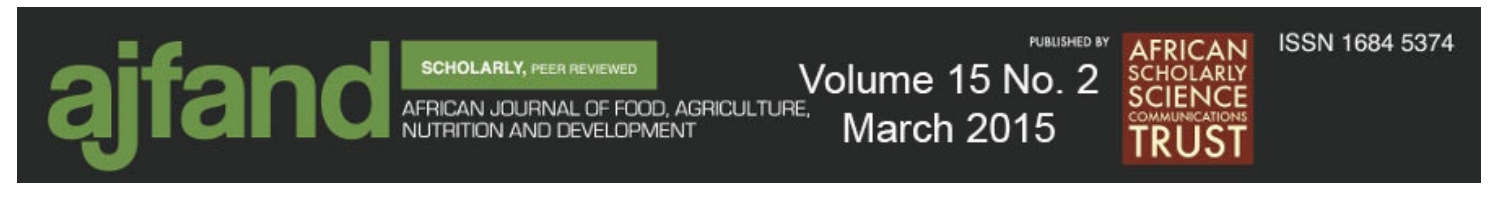

Table 1: Occurrence of pre- colonization pests in hives baited with four different baiting materials

Pest abundance

\begin{tabular}{|c|c|c|c|c|c|c|c|c|}
\hline \multirow[b]{2}{*}{$\begin{array}{l}\text { Baiting } \\
\text { materials }\end{array}$} & \multicolumn{2}{|c|}{2 Days post installation } & \multicolumn{2}{|c|}{3 Days post installation } & \multicolumn{2}{|c|}{4 Days post installation } & \multicolumn{2}{|c|}{5 Days post installation } \\
\hline & $\begin{array}{l}\text { Oecophylla } \\
\text { longinoda }\end{array}$ & $\begin{array}{l}\text { Camponotus } \\
\text { consobrinus }\end{array}$ & $\begin{array}{l}\text { Oecophylla } \\
\text { longinoda }\end{array}$ & $\begin{array}{l}\text { Camponotus } \\
\text { consobrinus }\end{array}$ & $\begin{array}{l}\text { Oecophylla } \\
\text { longinoda }\end{array}$ & $\begin{array}{l}\text { Camponotus } \\
\text { consobrinus }\end{array}$ & $\begin{array}{l}\text { Oecophylla } \\
\text { longinoda }\end{array}$ & $\begin{array}{l}\text { Camponotus } \\
\text { consobrinus }\end{array}$ \\
\hline Slum gum & $4.00 \pm 2.64 \mathrm{a}$ & $132.66 \pm 39.56 b$ & $12.00 \pm 2.51 b$ & $40.00 \pm 16.65 b$ & $3.67 \pm 3.66 a$ & $23.66 \pm 10.13 b$ & $0.67 \pm 0.066 a$ & $2.33 \pm 2.32 \mathrm{a}$ \\
\hline Bee wax & $0.00 \pm 0.00 \mathrm{a}$ & $0.00 \pm 0.00 \mathrm{a}$ & $0.00 \pm 0.00 \mathrm{a}$ & $0.00 \pm 0.00 \mathrm{a}$ & $6.33 \pm 3.48 \mathrm{a}$ & $0.00 \pm 0.00 \mathrm{a}$ & $0.00 \pm 0.00 \mathrm{a}$ & $0.00 \pm 0.00 \mathrm{a}$ \\
\hline Honey & $17.33 \pm 2.02 b$ & $105.00 \pm 14.04 \mathrm{~b}$ & $4.66 \pm 2.66 \mathrm{a}$ & $34.66 \pm 3.66 b$ & $14.33 \pm 5.69 a$ & $33.33 \pm 8.29 b$ & $0.00 \pm 0.00 \mathrm{a}$ & $4.66 \pm 3.28 \mathrm{a}$ \\
\hline Propolis & $0.00 \pm 0.00 \mathrm{a}$ & $0.00 \pm 0.00 a$ & $0.00 \pm 0.00 a$ & $0.00 \pm 0.00 a$ & $5.67 \pm 5.66 a$ & $0.00 \pm 0.00 a$ & $0.00 \pm 0.00 a$ & $0.00 \pm 0.00 a$ \\
\hline ANOVA & $F_{(3,8)}=24.32$ & $F_{(3,8)}=10.97$ & $F_{(3,8)}=9.55$ & $F_{(3,8)}=6.45$ & $F_{(3,8)}=0.97$ & $F_{(3,8)}=6.67$ & $F_{(3,8)}=1.00$ & $F_{(3,8)}=1.23$ \\
\hline & $\mathrm{P}=0.001$ & $\mathrm{P}=0.001$ & $\mathrm{P}=0.01$ & $\mathrm{P}=0.01$ & $\mathrm{P}=0.45$ & $\mathrm{P}=0.01$ & $\mathrm{P}=0.44$ & $\mathrm{P}=0.36$ \\
\hline
\end{tabular}

Means followed by the same letter along the column are not significantly different using Tukeys’ HSD at 5\% probability level 


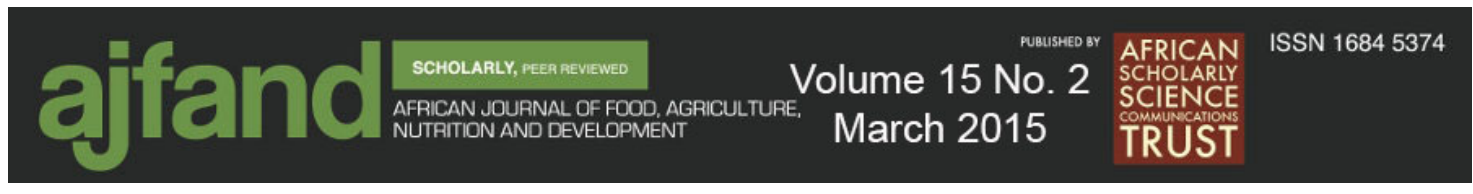

\section{REFERENCES}

1 Babarinde SA, Oladunjoye IO, Ojebiyi OO and SA Oyedeji Inclusion of honey bee slum gum in broiler chicken feed. Int. J. Agric. Biol. 2011; 13: 781785.

2 Ande AT, Oyerinde AA and MN Jibril Comparative study of the influence of hive types on bee colony establishment. Int. J. Agric. Biol. 2008; 10: 517-20.

$3 \quad$ Verma S and PK Attri Indigenous beekeeping for sustainable development in Himachal Himalaya. Ind. J. Trad. Knowl. 2008; 7(2):221-225.

Okwee-Achai J, Anyanzo TA, Aroba J, Vuchiri JK, Onzivua T and P Okullo Effects of apiary management on colonisation and colony performance of African honey bee (Apis mellifera) in the North-Western Agro-ecological zone of Uganda. Livestock Res. Rural Dev. 2010; Volume 22, Article \#86.[online] http://www.lrrd.org/lrrd22/5/okwe22086.htm. (accessed on 25 November 2011).

5 Aina DO and K Owonibi Beekeeping Prospects: Palynology and the Environment. Adv. Appl. Sci. Res. 2011; 2 (4): 79-85.

6 Babarinde SA, Akanbi MO, Adebayo TA, Olaifa JI, Odewole AF and EA Alagbe Effect of polythene and lime applied to top bars hive on colonization, weight gain and pest infestation. Ann. Biol. Res. 2010; 1(4):61-66.

7 Babarinde SA, Akanbi MO, Akinpelu FA, Oyelade BG and B Oyelami Impact of canopy type on honey bee (Apis mellifera adansonii) (Hymenoptera: Apidae) colony performance and pest infestation. Afr. Scientist. 2011; 11(3):169174.

$8 \quad$ Adjare S Beekeeping in Afica. 1990 [online] 1990.

http://www.fao.org/docrep/T0104E/T0104E01.htm (acccessed on 28 December 2004).

9 Suazo A, Torto, B, Teal PE and JH Tumlinson Response of the small hive beetle (Aethina tumida) to honey bee (Apis mellifera) and bee-hive produced vola-tiles. Apidologie 2003; 34: 525-533.

10 Bradbear $\mathbf{N}$ Bees and their role in forest livelihoods FAO Non wood forest product 19, FAO Rome, Italy, 2009.

11 Oyerinde AA and AT Ande Distribution and impact of honey bee pests on colony development in Kwara State, Nigeria. J. Agri. Soc. Sci. 2009; 5: 85-88.

12 Babarinde GO, Babarinde SA, Adegbola DO and SI Ajayeoba Effects of harvesting methods on physicochemical and microbial qualities of honey. J. Food Sci. Tech. 2011; 48(5):628-634. 
13 Babarinde SA, Odewole AF, Oyegoke OO and OB Amao Impact of hive dimension and fight entrance on hive colonization, pest infestation and hive weight gain in Apis mellifera adansonii (Hymenoptera: Apidae). Munis Ent. Zool. 2012; 7(1): 634-641.

14 Akachukwu CO Honey quality as affected by methods of harvesting and processing in Southern Nigeria. J. Agri. Tech. Environ. 2005; 1(1): 73-82.

15 Ande AT, Oyerinde AA and MN Jibril Comparative Study of the Influence of Hive Types on Bee Colony Establishment. Int. J. Agric. Biol., 2008; 10 (5): 517520.

16 Edet DI, Oladele AT and R Bekom The impact of coloured lights on night-time colony management of the African honey bee (Apis mellifera adansonii). Agric.Biol. J. North Am. 2012; 3(12): 506-509.

17 Onwumere J, Onwukwe F and CS Alamba Comparative analyses of modern and traditional bee keeping entrepreneurships in Abia State, Nigeria. J. Econ. Sust. Dev. 2012; 3 (13): 1-9.

18 Mutsaers M Honeybees in their natural environment in south western Nigeria. Nigerian Field, 1991; 56:19-28.

19 Gregory P Better Beekeeping in top-bar hives: Hives and hive making. Bees Dev. J., 2003; 68: 3-4.

20 SPSS SPSS Inc. Statistical Package for Social Sciences. Version 15. Headquarters 233 S. Warker Drive. $11^{\text {th }}$ Floor, Chicago, IL 60606, USA. 2008.

21 Neumann P, Pirk CWW, Hepburn HR, Solbrig AJ, Ratnieks FLW, Elzen PJ and JR Baxter Social encapsulation of beetle parasites by cape honeybee colonies (Apis mellifera capensis Esch.), Naturwissenschaften 2001; 88: 214216.

22 Wilson RT Current status and possibilities for improvement of traditional apiculture in sub-Saharan Africa. Livestock Research for Rural Development. Volume 18, Article \#111 [online] 2006. http://www.lrrd.org/lrrd18/8/wils18111.htm (accessed on 20 March 2010).

23 Buckley A, Saville N, Carroll T and G Rita An introduction to beekeeping, Progressive interventions, The enterprise Development Agency. 2004. 